\title{
Editorial
}

\section{Abstracts of the 42nd Annual Meeting of the Society for Neuropediatrics}

\author{
Ulrike Schara ${ }^{1}$ Thomas Lücke ${ }^{2}$ \\ ${ }^{1}$ Department of Neuropediatrics, Developmental Medicine and Social \\ Pediatrics, University Children's Hospital Essen, University Duisburg- \\ Essen, Germany \\ 2 Department of Neuropediatrics, University Children's Hospital, Ruhr- \\ University Bochum, Bochum, Germany
}

Neuropediatrics 2016;47(Suppl 1):1.

For the 42nd Annual Meeting of the Society for Neuropediatrics, which takes place in Bochum and Essen from 21st to 24th April, 2016, a total of 204 submissions were accepted for free articles presentations, poster presentations, video sessions, and scientific program sessions. The English abstracts of these submissions are now published in this online supplement of Neuropediatrics. The abstracts can also be accessed through the "List of Authors"-an online author index-which will be available at: https://www.thieme-connect.com/products/ejournals/issue/10.1055/s-006-31610 and will assist the reader to get automatically directed to the respective abstract.

On behalf of the Gesellschaft für Neuropädiatrie, we thank all colleagues for the submission of their abstracts and the publisher, Georg Thieme Verlag KG, for making our scientific contributions available to the international readership.

Please cite the individual abstracts in the following format: Author names. Abstract title. In: 42nd Annual Meeting of the Society for Neuropediatrics; April 21-24, 2016; Bochum/Essen, Germany. Available at: https://www.thieme-connect.com/ products/ejournals/issue/10.1055/s-006-31610. Neuropediatrics 2016;47(Suppl 1):Abstract Number.

Enjoy reading!

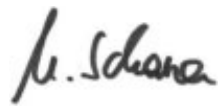

Prof. Dr. med. Ulrike Schara [Co-Chair, Gesellschaft für Neuropädiatrie]

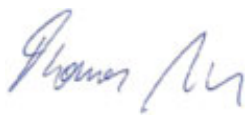

Prof. Dr. med. Thomas Lücke

[Co-Chair, Gesellschaft für Neuropädiatrie]

Address for correspondence Prof. Dr. med. Ulrike Schara, Department of Neuropediatrics, Developmental Medicine and Social Pediatrics, University Children's Hospital Essen, University Duisburg-Essen, Essen, Germany (e-mail: Ulrike.Schara@uk-essen.de). (c) 2016 Georg Thieme Verlag KG Stuttgart · New York
DOI http://dx.doi.org/ 10.1055/s-0036-1583309. ISSN 0174-304X. 